ARTICLE

\title{
GENDER EQUALITY IN TUNISIA: CURRENT TRENDS
}

\author{
Kashina, Anna $*^{a}$ \\ a. Diplomatic Academy of the Ministry of Foreign Affairs of Russia, Moscow, Russia \\ * Corresponding author (a.kashina@dipacademy.ru)
}

PUBLISHED: 19/07/2021

\section{COPYRIGHT NOTICE:}

(C) 2021 by author. Licensee ERUDITUS. This article is an open access article distributed under the terms and conditions of the Creative Commons Attribution (CC BY) license (https://creativecommons.org/licenses/by/4.0/ ).

\section{CITE THIS PAPER:}

Kashina, Anna 2021. "Gender equality in Tunisia: current trends" Journal of Social Sciences: Transformations \& Transitions (JOSSTT) 1(01):04. DOI: https://doi.org/10.52459/josstt1140721

\section{ABSTRACT}

Tunisia has come a long way towards achieving gender equality and remains a prominent example to other Arab countries in this experience. Meanwhile, Tunisia still takes only modest positions in international rankings on various indexes measuring gender gap. This work examines, with the help of a comparativehistorical method, the formation of the women's movement in Tunisia and the development of legislation on gender equality. Then, through statistical data the author outlines the extent of women's economic, social, and political participation, and, finally, referring to the "concept of representation" by Hanna F. Pitkin (1967), the author looks at the pre-election programs of political parties that won the 2019 parliamentary elections, in order to assess the perception of the problem of women's emancipation in Tunisian society on the whole. As a result of the research, the author comes to the conclusion that, despite progressive legislative framework guaranteeing women's rights, the mass consciousness of Tunisians maintains a set of ideas and norms on gender inequality generated by Islamic tradition and fostering the discrepancy, first in the existing legislation and the objective reality, and secondly, between the rules of family law containing elements of Sharia, and the provisions of the Constitution, as well as the accepted international obligations.

\section{KEYWORDS}

Tunisia, Gender equality, Code of Personal Status, Feminism, Political participation, Women's rights, Political Islam 


\section{INTRODUCTION}

Tunisia's experience as an Islamic country, where men and women have almost equal legal rights for more than half a century, is unique. In 1956, at the dawn of independence, the Code of Personal Status (CPS) was introduced in the Republic, under which Tunisian women were entitled to education, employment, marriage on their own decision and even divorce, which was rare for a Muslim country. Gender equality in Tunisia has since been strengthened, but the Arab Spring and the ascension of Islamists to power after 2011 have once again put the issue of women's place in society on the agenda. On the streets of the capital flashed beauties in hijabs and niqabs, perhaps for the first time in fifty years. However, the crisis of identity at a tipping point was not resolved by the triumph of traditional values. In 2015, the post of mayor of the capital for the first time went to a woman - Souad Abderrahim, a member of the Islamist Ennahda movement. And in 2019 during the regular general elections the essential point of any electoral campaign was the position on the inheritance gender-equality bill. An amendment to the CPS providing inheritance gender-equality would be a triumph of democratic values in Tunisia. To what extent does this legislative initiative in fact reflect the current situation and what are the main trends in the focus of gender balance in contemporary Tunisia?

\section{METHODOLOGY}

The work is based on the conceptual approach of sociologist Mounira Charrad (1997), who presents the gender factor in Tunisia as the object of constant politicization:

"In Tunisian state policy on women's rights have been a by-product of struggles among social and political groups fighting over state power". (Charrad, 1997:285)

The purpose of this work is to examine, with the help of a comparative-historical method, the formation of the women's movement in Tunisia and the development of legislation on gender equality, then by analyzing statistical data to outline the extent of women's economic, social and political participation, as well as, based on the "concept of representation" by Hanna F. Pitkin (1967), to analyze the electoral campaign of political parties that were in 2019 elected to form the parliament, in order to assess the perception of the problem of women's emancipation in Tunisian society.

\section{RESEARCH}

\subsection{The evolvement of women's movement in Tunisia}

The theoretical basis for the women's movement in the Arab countries, which was certainly born under the influence of Western thought, was laid by the works of such Arab thinkers of the 19th century as Butrus al-Bustani, Francis Marrash, Rifa'a al-Tahtawi and Qasim Amin. All of them associated social development 
with the "liberation" of a woman, the assertion of her social role not only as a mother and wife, but as a full participant in public affairs. "Familiar with Islamic law (Sharia)," - wrote Q. Amin in "The New Woman" (1901), - "knows that the liberation of a woman is one of its precious foundations", by which a woman has the same rights as a man to "assertive management and full control of her wealth", to education and training, decision "on what kind of craft or specialty to pursue" (Amin, 1972: 11-12).

The "classic of emancipation" in Tunisia is Tahar Haddad, who explained in the book "Our Women in the Shari 'a and Society" (1930) the disparage position of an Arab woman with a distorted understanding of religious laws, which, according to the philosopher, should be inviolable and eternal, but only those that do not contradict the changing conditions of reality and "do not harm Islam", whereas "the treatment of slaves, polygamy and the like cannot be seen as part of Islam." Polygamy was considered by the thinker to be a relic of the pre-Islamic era and according to Haddad, in the time of the Prophet they began to fight it, therefore the fourth chapter of the Quran - Surat An-Nisa', Ayat 3 (4:3) - was supposed to be a warning not to marry more than one woman, for it was impossible to be equally fair to two, three or four wives at a time. As a supporter of Ijtihad (independent interpretation, one of the sources of Islamic law), Haddad believed that the postulate of a double share of inheritance for a man of that for a woman could be easily adjusted in favour of equalization of shares, based on the principle "for women there is reward for what they have earned" set out in Ayat 32 of the same Surat An-Nisa' (4:32), which Haddad took for women's freedom of wealth management. Haddad's work embodied the quintessence of earlier ideas and provided a rationale for the absolute equality of men and women in all spheres without exception.

It should be noted that long before the publication of "Our Women in the Shari 'a and Society" the Tunisian public was greatly impressed by the works of the Egyptian philosopher Qasim Amin. Already in the first quarter of the 20th century, Tunisian newspapers and magazines boldly discussed the issue of women's empowerment. Among the publications that challenged the idea of social equality between men and women are the newspaper Khair al-Din and al-Khadira. On the contrary, the idea's defenders were, for example, alRa'id al-Tunisiy, al-Nahda, al-Sawab, Murshid al-'Umma, Lysan al-'Arab and al-Badhar, al-'Alam al- 'Adabiy. They gave admiring details about the meeting of women's clubs in Middle Eastern countries, discussions including the relevancy of wearing an Islamic veil, ordinances, and various appeals to local administrations, particularly regarding the need for women's education. From issues of al-'Alam al-'Adabiy magazine throughout the year 1930 Tunisian readers learned that in Turkey women gained the right to vote, to representation on local administrative boards and the right to act as judges, in Iran women organized their own cultural salon and established the magazines 'Alam Niswan and Zabane Zinan, Muslim woman Zeinab Kamal received the Chemistry Prize in England and was appointed dean of the University of Egypt (the present Cairo University) (ālid, 1985: 234). 
Given that almost any reform regarding the status of women caused a storm of indignation among clerics and conservatives, of all the variety of topics at first it was women's education that caused them the least resistance and was the most discussed on the street. In 1909, by that time the French protectorate (18811956) was established in Tunis, there were only three schools for Muslim girls: two in the capital and one in the city of Sousse, with French being the teaching language there as the directors were foreigners - Louise Rene Millet, the wife of the French resident general, and Mrs. Eigenshenk. Tunisian reformers, of course, advocated compulsory study of Arabic, as well as Arabic philosophy and literature within the school curriculum, with the participation of teachers from Syria and Egypt, not France. The conservatives also stressed the importance of teaching girls housekeeping. Under the pressure of criticism and mass discussions, the authorities of the protectorate had to cede ground and established Franco-Arab schools. By 1940, there were 3,700 female-students enrolled there. Meanwhile it was not until 1958, two years after independence from France, that Tunisia underwent a reform that made primary schooling compulsory and free for all children over 7 years of age, boys and girls. Over time, the focus of the debate on women's place shifted from education to economic participation and trade union activism (1970s-1990s) and, finally, to political participation (especially after 2011).

The first women's societies in Tunisia were born in the era of the French protectorate. When in 1932 due to heavy rains and floods there was a crop failure, and many families were left with virtually no means of subsistence, help came unexpectedly. In January, a group of Tunisian women formed a charity, the Muslim Women's Society, led by Fatima Qalati. They managed, with the help of the wife of the then resident general François Monceron and the daughter of prominent Tunisian politician Bashir Sfar, to hold a series of open evenings in the capital's mansion near the current residence of the Government and raise funds for the victims (Hālid, 1985: 268). This was the first stone of the Tunisian feminist movement. Such cultural and charitable evenings were loved by the audience, that came to listen to entertaining and rather convincing speeches about the role of women in Islam, the proper way of interpreting religious norms and the obligation of women to benefit public development. In 1936, the first Tunisian magazine about and for women "Leila" was founded women entered the publishing field and began to write for and by themselves (previously it was done by men).

On April 8, 1938, the pioneer of the women's movement Bchira Ben Mrad organized a political demonstration, where about a hundred Tunisian women protested in the capital near the headquarters of the resident general against colonial repression. Since that first experience, women fought time and again for the country's independence, some of them were imprisoned and injured during anti-colonial demonstrations. In this struggle, women were able to prove their resilience, determination, and former opponents of female emancipation moved to their side, supporting women's unions.

New names added to the list of women's societies - the Union of Muslim Women of Tunisia (formed in 1938, officially registered in 1951), the female section of Young Muslims' Association (1947), the Tunisian 
Girls' Club and the Union of Tunisian Women (UFT, 1940), and others gradually came up with the idea of a united national women's organization, which would integrate previously created structures. Thus, in 1956, the National Union of Tunisian Women was founded, the largest female non-governmental organization in Tunisia at the time. Meanwhile, once the country's Ministry of Women and Family Affairs was formed in 1983[1], feminists were brought under government control and kept "within narrow limits" until 2011 (Brand, 1998: 307-320). This policy has been dubbed "state feminism" (Murphy, 2003) or "institutional feminism" (Bessis, 1999). In addition to the National Union of Tunisian Women, the Ministry also "coordinated" with the National Council for Women and Family Affairs, the Centre for Research, Studies, Documentation and Information on Women (CREDIF, established in 1991) and the National Commission for Women's Rights and Development. Meanwhile, relatively independent women's organizations continued to emerge. A good example is the Tahar Haddad Club, which published the magazine Women (Nissa') for a short period between 1985 and 1987, expressing a desire to come out of party (state) control and represent an independent civil movement, authentic and free from the influence of Western feminist thought. The Tunisian Association of Democratic Women (ATFD) was founded as "independent" organizations in 1982 and the Association of Tunisian Women for Research and Development (AFTURD) in 1989. Both have shown themselves extremely engaged in promoting gender balance since the so called 2011 Revolution for Dignity and Freedom, declaring their activities as "democratic feminism" (Daniele, 2014: 23).

The emergence of Muslim feminist organizations and more broadly "Islamic feminism" has become quite an interesting phenomenon of the post-uprising period. For example, the Tunisian Women's Association, which represents "Tunisian Muslim women", aims to unite victims of discrimination and political repression (within the period of Z.A. Ben Ali dictatorship) who experienced violence, including political violence. It is also important to note the vigor of Muslim women from Ennahda movement, who advocate social guarantees, justice, and rights for women not within the traditional for feminist movements liberal paradigm, but within the religious one.

Until 2011, the main feature of the women's movement was elitism: it invariably included representatives of influential families, and activities were concentrated in the capital and the Tunisian Sahel (privileged seaside central-eastern region). With the fall of Ben Ali's regime on January 14, 2011, the women's movement in Tunisia reached a new level. First, the activism of all citizens, and of course women, in various party structures and non-governmental organizations, including the women's ones, has increased. Secondly, women's movements were able to carry out really serious, sometimes oppositional work. They began to fight not only for strengthening of their rights, recognition and observance of legislature on their rights, increasing participation in social life, but also for the first time insisted on the revision of the social structure, perception of gender. These efforts were made by ATFD, AFTURD, the Association of Women's Voices, the Committee for the Study of Women in Tunisia, and others. And thirdly, women's movements began to attract funding to establish an extensive network of regional offices. 
The chief problem that Tunisian feminists are facing is their structural and ideological fragmentation, which in general does not allow to speak about complete formation of a holistic women's movement in Tunisia, which would have a clear agenda (Marzouki, 1999:7). In addition, most women's organizations consist of members over 50 years old [2], while girls from "revolutionary youth" in their ranks are still few and rare. This raises the question of the continuity of generations within women's organizations.

\subsection{Women's economic, social, and political representation}

According to the World Economic Forum's Global Gender Gap Report 2021, Tunisia was ranked 126th out of 156 countries and third in the region after Israel and the UAE, which, given the overall socio-economic climate in the North African country, is particularly good. And in 2018, Tunisia even rose in the regional ranking to the second place, then ranked 119th out of 149.

The report confirmed that Tunisian women have earned most notable achievements in education. Enrolment in primary and secondary school proved parity between both sexes, certainly due to the introduction of 1991 educational reform that made compulsory both primary and secondary education. In high school, the number of girls was twice as high as the number of boys in the 2018/2019 academic year: 154,000 female scholars against 80,000 male scholars (Annuaire Statuesque, 2019: 60). In addition, schoolgirls and female students, on average, more successfully master all areas of knowledge except technical (Les Femme en Tunisie, 2002: 33). Probably, already at this stage girls become victims of groundless cliches and stereotypes and rarely devote themselves to engineering or fundamental sciences. They prefer services, humanities, or medicine. Among female graduates, only about $29 \%$ receive a diploma of engineering. Of the faculty in the 2012/2013 academic year, only 17\% were women (Gribaa, Boutheina, Depaoli, 2014: 85).

In addition, illiteracy among women in Tunisia is higher than among men: 27.8 per cent versus 13.9 per cent. The National Literacy Programme was adopted in 1992, but it probably did not affect all citizens, especially the elderly rural inhabitants.

The situation with narrowing gender gap is rather adverse in the economy. According to the World Economic Forum's estimates, Tunisia's index was 0.445 (with a maximum of 1), lower than in neighboring Algeria (0.456), but higher than in Morocco (0.407) and Egypt (0.421). Discrimination stands out in terms of employment in high-paid as well as senior management positions, where there are very few women, because 85 per cent of such posts go to men. Women still have great potential to enter the labour market because the ratio also reveals a significant gap: 72 per cent of workers were males, and only 28 per cent females (Recensement Général, 2017: 20). While in Tunisia the employment rate for men (75.5\% in 2021) was nearly the same as global average (76.1\%), for women this indicator (28.1\% in 2021) was higher than the average for 
Arab countries (21.2\%), but markedly lower than the global average (50\%) (World Employment, 2021). The dynamics of the employed population by gender have been presented in the Chart No.1, based on the data retrieved from Recensement Général (2017: 20).

Chart 1. The dynamics of the employed population by gender in $\%$

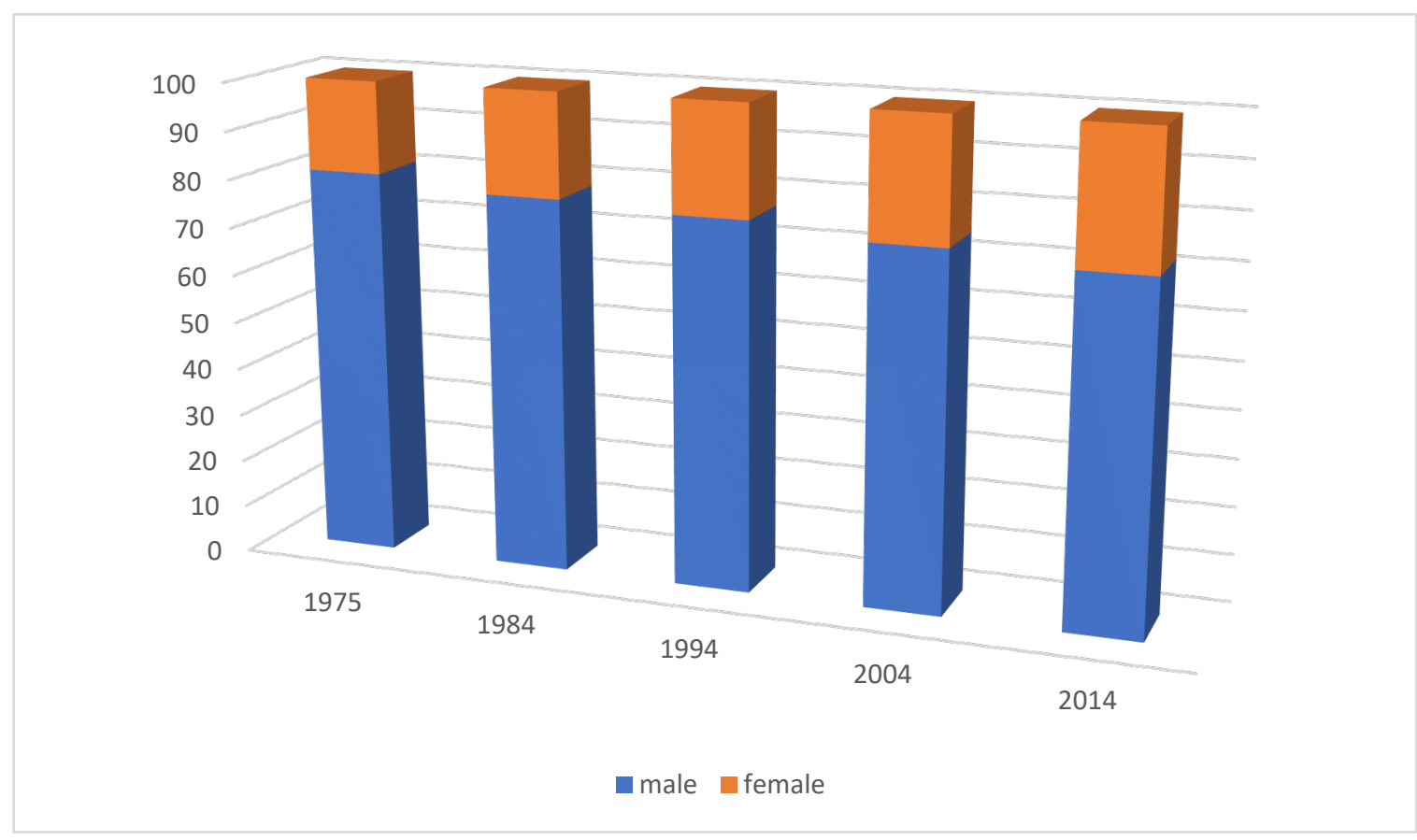

In the 1990s, N. Voronchanina drew attention to the fact that the European concept of female emancipation is not suitable for Arab countries, as it implies the inclusion of women in the sphere of labour market without taking into account the situation when it is overcrowded with the "army of unemployed men" (Voronchanina, 1998: 117). This is still true in Tunisia: men accounted for 53.4 per cent of the unemployed in 2014 (Recensement Général, 2017: 31-32). However, the unemployment rate for women was almost twice as high. For example, in 2015 this indicator reached 12.4\% among men and 22.2\% among women, and in 2018 this ratio remained virtually unchanged: 12.5\% vs. 22.7\% (Annuaire Statuesque, 2019: 109). Moreover, official statistics consider only those registered on the Labor agency, so, there is reason to believe that there are much more job seekers. This data may indirectly indicate gender discrimination in employment. "With no more than a quarter of the workforce, women are the first victims of crises," writes a prominent Tunisian sociologist Ben Romdhane (Ben Romdhane, 2011: 175-176), pointing out that during the global economic crisis of 2009, all 43,000 newly created jobs were distributed to men, and another 11,000 men were employed after the dismissal of women. Meanwhile, women's involvement in the Tunisian labour market has been slow in the past 40 years, but a steady growth trend, as opposed to the declining share of men. Therefore, in the long term, if current trends continue, equality in the labour market, at least in quantitative terms, is expected. 
The positive dynamics presented in Table 1 are not least a consequence of important legislative measures taken by the Tunisian authorities in the 1990s. These are, first of all, amendments to the Code of Personal Status, introduced in 1993, and in particular, Article 23 of the document that formerly stated that "a woman should obey her husband in everything as head of the family" and then was replaced by "a woman is obliged to contribute to the family budget if she has the financial capacity". Sadok Chaabane, the then justice minister, commented on this as "a new, extremely important principle of mutual assistance for spouses" (Sraieb, 1997: 70). In addition, in 1996 to the Labour Code (adopted in 1966) was added article 5, prohibiting labour discrimination based on sex, and article 135 removed the wording of a special "wage for women". Law 58 of 11 August 2017 prohibiting discrimination against women enshrines the principle of equal treatment of gender and prohibits "economic" and "financial" discrimination against women, including wage, working conditions or career's opportunities (article 19).

In order to protect their labour rights, in 1984, the Tunisian General Labour Union (UGTT, the main trade union with a number of members over 650,000) formed the Committee of Women Workers, which in 2000 became an integral part of the organization under its Charter. The head of the Committee participates as an observer in the National Governing Council of the UGTT. Although the share of women in the trade union exceeds 45\%, according to 2013 data, in its leadership it was no more than 5\% (Gribaa, Boutheina, Depaoli, 2014: 49). Therefore, the election of a leftist woman activist Naima Hamami deputy secretary general and a member of the Executive committee of UGTT in 2017, for the first time since 1949, can be considered a significant event. Moreover, in 2017, the UGTT fixed a quota for the mandatory inclusion of at least two women in the governing bodies of the trade union at all levels [3], and ran a campaign with the support of the International Labour Organization to attract new female members. As a result, the trade union accepted about 13,000 new female members (Changing Laws, 2020: 96).

As far as the gender ratio in parliament and the cabinet is concerned, Tunisia is second to another Arab country, the UAE, according to the 2021 Global Gender Gap Report. In these state bodies the number of women rarely exceeded 30 per cent. In the Chart 2, the proportion of women in Tunisian Parliament during the 1999-2020 has been shown based on the World Bank Data (The World Bank Data, 2021). 
Chart 2. The proportion of women in Parliamentarian in 1999-2020, \%

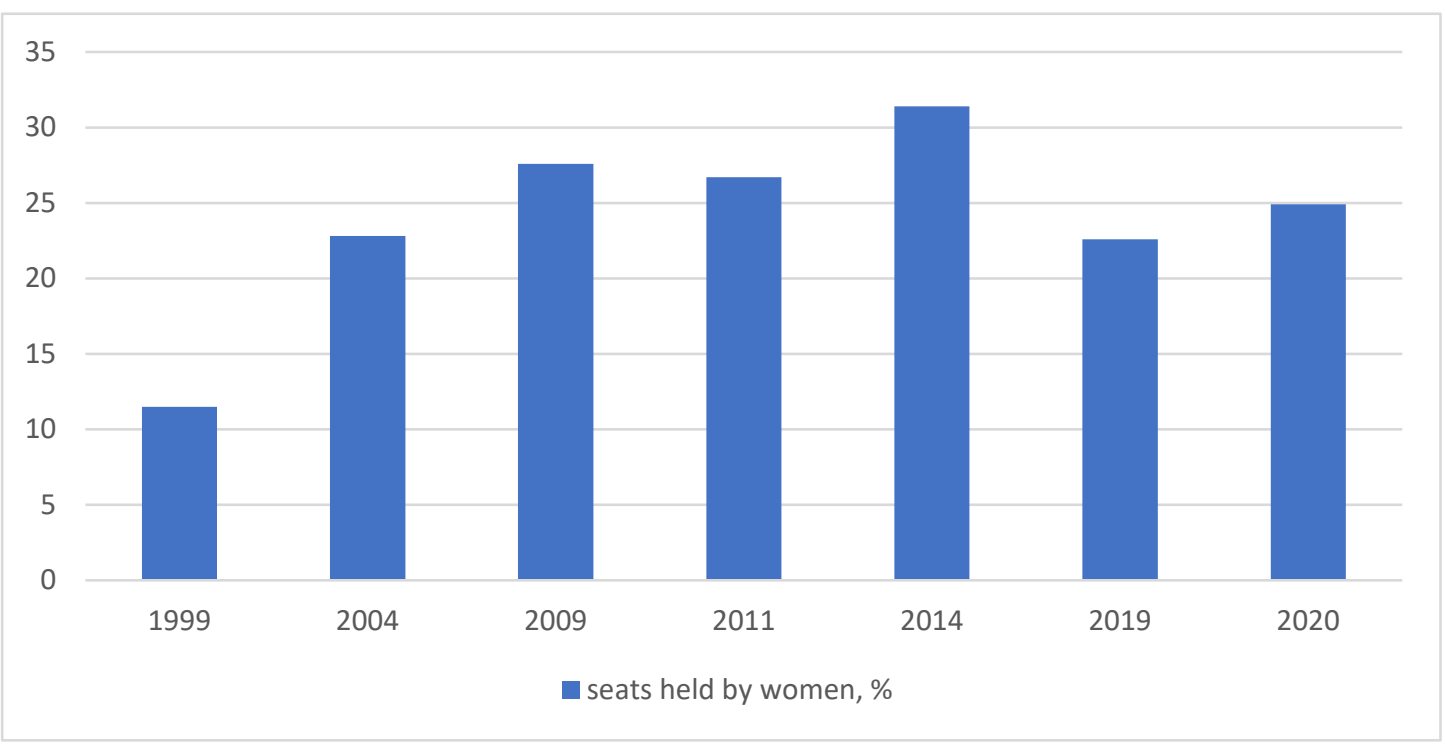

In 1994, women accounted for only 7 per cent of the total number of deputies elected to Parliament, which was higher than the regional average. After the 2009 parliamentary elections, women have already won 27.6 per cent of the seats ( 59 out of 214 ), which is more than in the previous parliament $(22,8 \%)$. The Tunisian National Constituent Assembly (2011-2014) first included 49 women (23\% out of 217), but then expanded number of female members. In the 2014 parliament, the proportion of women rose to $31 \%$ (68 seats out of 216), for which Tunisia was awarded the 2015 Women's Parliamentary Forum Award. There were fewer women in the 2019 parliament than in the previous one, with most of the female parliamentarians being Ennahda MPs. As for the composition of the Cabinet of Ministers, until 2011, women headed one or two ministries: traditionally the Ministry of Family and Women's Affairs and one more. For example, in 1984 ministry of health, 1999 - ministry of natural resources, in the government of 2014 under the leadership of women passed the Ministry of Tourism and the Ministry of Trade and Industry. In successive governments the number of women ministers increased, they managed the Ministry of Finance (2016), Energy (2016), Justice (2020), etc. In the Cabinet of Hicham Mchichi, formed in August 2020, women won eight seats, including the portfolios of the Minister of State Property and Real Estate, the Minister of Agriculture and Water Resources, the Minister of Industry, Energy and Mines, the Minister of Family Affairs, Women, and the Elderly in addition to the portfolio of Minister of Higher Education and Science.

Until 2009, each party had to quota women's participation among its candidates for the elections. For the former party of power, the Democratic Constitutional Rally it was 30 per cent. The same rule has affected the composition of regional councils of provinces (governorates) since 2004. In May 2004, Salwa Mohanssi was appointed by presidential decree governor of one of the provinces for the first time. In 2015, MP Souad Abderrahim took over as mayor of the capital. 
Legislation on the rights of women's political participation has been forming for quite a long period. The issue of political rights for women was first formally raised in 1953 by the efforts of prominent Tunisian feminist Bchira Ben Mrad. In June 1956, the Municipal Council Elections Law was passed, giving women the right to vote. The 1959 Constitution then enshrined the equal right of men and women to vote and to be elected. Article 21 of the 2014 Constitution refers to the equal rights and responsibilities of citizens, men and women, their equality before the law, equal opportunities, and the right to a decent life, as well as the prohibition of discrimination, and article 46 claims their equal opportunities to participate in elected bodies. The principle of gender equality is repeatedly mentioned in the Development Programme 2016-2020 (part 4, paragraph 3). The women's presence at the municipal and party levels was also strengthened by Law of 26 May 2014 on the elections and referendums.

At the international level, Tunisia signed the Convention on the Political Rights of Women in 1968, and in 1969 joined the United Nations International Covenant of Civil and Political Rights (ICCPR). Tunisia fully adopted the provisions of the International Convention on the Elimination of All Forms of Discrimination against Women (CEDAW), which was originally ratified by Tunisia in 1985 with numerous reservations. In 2018, Tunisia signed the Protocol to the African Charter on Human and Peoples' Rights on the Rights of Women in Africa (the Maputo Protocol). Participation in such international pacts and conventions is an important fact because Article 20 of the 2014 constitution states the primacy of international law over domestic law.

Women were involved in almost all the important events that took place after the Arab Spring. It should be mentioned that in 2011 women actively attended demonstrations, had a representative in the membership of the Independent High Authority for Elections (ISIE) - Souad Triki (among current members is Hasna Ben Slimane), ran as deputies and worked as observers in all municipal and national parliamentary and presidential elections. Meanwhile in Tunisia, a woman politician or leader is an exception rather than a rule. Among those who serve as a prominent example are the Chairman of the Tunisian Confederation of Industry, Trade and Handicrafts (UTICA) in 2011-2018, Vided Buchamaoui, the head of the Free Destourian Party represented in Parliament, Abir Moussi, the head of the Progressive Democratic Party, the legendary Maya Jribi, who died in 2018, and, of course, the vice-president of the Independent High Authority for Elections, a well-known human rights activist Souad Triki, mentioned above. However, these heroines can be counted on the fingers of one hand. Like most women in the world, they must choose between family and work in the face of a lack of social structures that help women be devoted to career.

\subsection{The Code of Personal Status of 1956 - isn't it time to change it?}


After the 2011 uprising in Tunisia in the context of general legislative framework revision, and in the light of the moderate Islamic movement Ennahda dominance at the time, there was concern about possible amendments aiming at the restoration of Sharia law. A good illustration of this situation will be the heated discussion of Article 28 of the new constitution draft, where Islamists insisted on the wording of "women's complementarity to men" rather than "gender equality". However, despite the pressure of Islamists, the Tunisian constitution of 2014 enshrined the "civil character of the state" and the "rule of law", and the status of Islam as a state religion remained in it, but without mentioning it as an official source of law. Fortunately, the Code of Personal Status of 1956 was not affected by changes as well. Moreover, Ennahda MPs voted in the National Constituent Assembly on 6 December 2011 to make CPS a constitutional law, meaning parliament cannot decide to amend it by a simple majority vote. The fact is that although the wordings of the CPS, introduced by decree of 13 August 1956, were "European" in form, they were based on Sharia in the content and de jure did not abolish Sharia. This was the main innovation of the first President of Tunisia, Habib Bourguiba, who is justly entitled the "liberator of women", because the adoption of the CPS overnight brought the family and social status of Tunisian women closer to that the fair sex has already won, but over a long period, in the West.

The essence of the 1956 family law reform was to abolish, in fact, the then unified Muslim law and bring it closer to European standards. No doubt it was a success: the CPS almost completely equalized the rights of men and women before the family, society and the state. Tunisia has become the most advanced Arab country in terms of the westernization of the legal framework for women's rights and freedoms. When the Egyptian leader Gamal Abdel Nasser visited Tunisia in 1965, he confided that he was delighted that due to CPS Tunisian women were free to leave without the consent of their father or husband, to study, to work and help modernize the country. Then Bourguiba replied that in Egypt such a law should have been adopted no later than 1954, because in Tunisia it appeared in 1956, at the dawn of independence and almost lightning fast, for six or seven meetings of the Council of Ministers (Voronchanina, 1998: 118). - "If I had even been a few months late, explained Bourguiba, it would not have worked" (Klibi, 2012: p. 100-103).

The CPS is considered a merit of President Bourguiba and was put in place only due to his foresight and personal authority. Nevertheless, being a courageous reformer, Bourguiba could not afford to ignore the opinion of the people and Ulama. The plan was carried out owing to the support of the Grand Mufti and the grandiose work of legal scholars (faqihs) to justify the rules of the new law with appropriate interpretations of Sharia (Muslim law). The only thing that could not be changed was the rule of inheritance prescribed directly in the Quran: for a woman half of a man's share. Neither Bourguiba nor the next President, Ben Ali, dared to repeal this discriminatory article. Unexpectedly, this issue returned a few years after the so-called Arab Spring.

Speaking on the occasion of Women's Day on 13 August 2017, Tunisian President Beji Caid Essebsi, the country's first freely and democratically elected president, stressed that "the equality of men and women enshrined in the Tunisian Constitution should apply to all areas, including the right of inheritance" (Ganmy, 
2017). In June 2018, a team of specialists under the administration of Caid Essebsi, the Tunisian Committee for Personal Freedoms and Equality (COLIBE), developed and submitted to Parliament a series of reforms set out in the 233-page document. The second part of the document focused on gender equality, and, among other things, proposed to abolish the "mehr" (dower for marriage), to prohibit the condemnation of the activities of sexual minorities, and to completely equalize the rights to inheritance of men and women. Probably, Caid Essebsi, the politician of the epoch of Bourguiba, whose zealous admirer he was throughout his life, was very eager to complete what his idol started. However, whether the authority of Caid Essebsi was not enough, or the right moment yet has not come, but the President's new initiative caused a stir in society.

The bill would not be passed quickly - discussions dragged on. Public attitude towards the bill has become one of the political markers that divided Tunisian society into supporters of Western values and adherents of the traditional, Muslim way of development. Meanwhile, the enormous controversy was approaching the point of no return, and the crisis after the likely adoption of the law could only be compared to the crises of 2013, when after a series of political assassinations blamed on the Islamists of Ennahda, Tunisia actually found itself over the abyss of civil war. However, the "new revolution" in Tunisia did not happen the bill never saw the light. Initially, in November 2018 it was approved and adopted by the Council of Ministers. In December 2018, it was submitted to Parliament for discussion and considered in several readings, but six months later, with the death of President Caid Essebsi on July 25, 2019, was placed on a shelf and left to oblivion. "The bill on gender equality in inheritance seems impossible now, without Caid Essebsi", MP Riyadh Ben Fadhel admitted in August 2019 to Independent Arabia (Trabelsi, 2019). Despite this Essebsi still managed to do something useful: in September 2017, he lifted the 1973 ban on the marriage of a Tunisian Muslim woman to a man of other faiths.

The importance of the democratic initiative of Caid Essebsi cannot be overstated: it has revealed society's attitude towards gender equality, a necessary element of democratic transition. Moreover, the issue of inheritance equality was almost a mandatory part of the parties' electoral programmes in the 2019 parliamentary elections. Providing that nearly all the participating parties and movements, with few exceptions, expressed their position on the issue, it was easy to study these preferences and obtain a "miniature map" of the attitude of Tunisian society to the question of inheritance equality, and therefore the idea of absolute gender balance.

In order to assess the degree of support for gender balance in the society, we have accepted that in the context of relatively democratic elections and rather high turnout, the Tunisian Parliament consists of political forces that broadcast the positions of the whole society. Then it is possible to extrapolate the ratio of parliamentary parties that support or reject the bill on inheritance equality to the ratio of these preferences in society. Careful examination of the parties' stances from domestic and international Mass media (Al-Jazeera, BBC, CNN Arabic, Alhurra, France 24, Orient XXI, Tunis Ultra, Shems FM, Mosaique FM, Watania News, 
Independent Arabia etc.) reports proved that the inheritance bill was extremely controversial. The results, based on the author's examination of Mass media reports during 2019 electoral campaign. are presented in the Chart 3 as following: 114 - Against, 50 - In favour, 22 - Abstention.

Chart 3. Differentiation of Parliament's positions on the Inheritance Equality Bill.

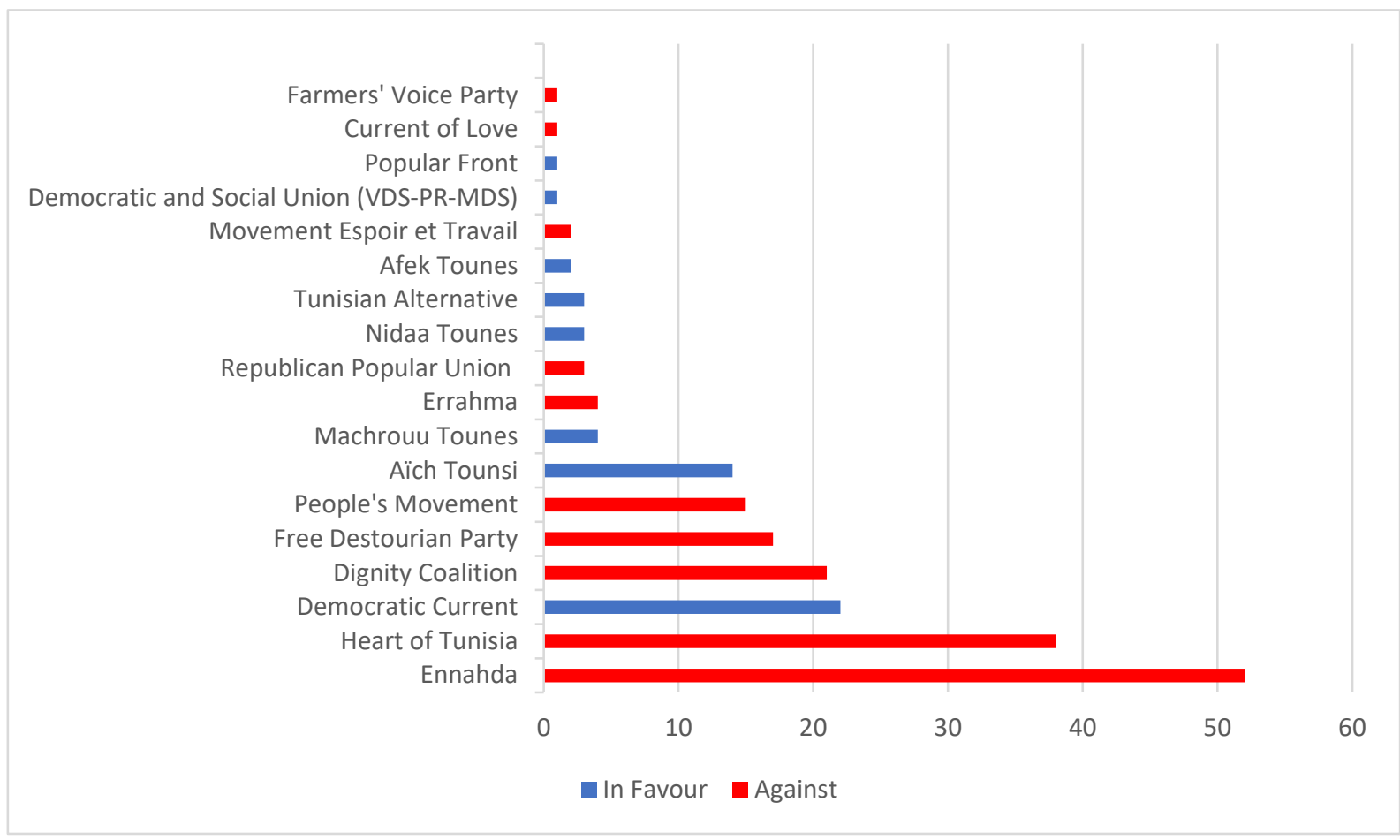

It is noteworthy that some parties have used their open position on the issue of inheritance equality to attract the electorate, while others, on the contrary, have evaded clear definitions, leaving for the people the right of choice. Independent candidates or smaller parties, or parties without unity of sentiment on the matter, generally preferred to hide their stances. But even after adding such group to those who supported the bill, the advantage will remain on the side of opponents who rejected the idea of inheritance equality.

On what grounds did the politicians oppose or support the bill? A petition rejecting gender equality in inheritance was signed by a number of nationalist parties - the Movement of free unionists of Tunisia, the AlMourabitoun movement, the People's Bloc for Tunisia, the al-Ghad party, the People's Movement, etc. The nationalists pointed out that under the 2014 constitution, Islam is the state religion in Tunisia, and therefore rules contradicting Islam cannot have the force of law. The perception of the state and religion unseparated is not unique to nationalists. Among opponents of the package of secular reforms were, of course, the moderate Islamists of Ennahda movement. Although at first the movement did not reject the draft law, in the end it signalled quite clearly that it would not vote for it in Parliament. This position was without doubt dictated by the fear of losing the electorate, represented by the conservative intelligentsia, as well as traditionally minded residents of the hinterland. 
On behalf of the Heart of Tunisia party that came second in the 2019 parliament elections, its leader, Nabil Karoui, endorsed all proposed liberal initiatives except equality in inheritance, which he said would "divide Tunisian society". While the Democratic Current not only supported the principle of equal inheritance, but also proposed to put the issue to a referendum as soon as possible, "given the sensitiveness of the issue in society and in order to avoid public schism". In turn, the chairman of the liberal Free Destourian Party Abir Moussi criticized the bill because of vague and ambiguous wording, which instead of firmly enshrining the principle of equal distribution of inheritance among heirs does not exclude an alternative traditional method of partition, and thus gives cause for discord in families.

Meanwhile, secular circles, mainly liberals and leftists, seemed determined to accomplish the reform path initiated by the first President of the Republic of Tunisia. They considered the issue of inheritance equality in the light of the precise implementation of the constitutional principle of equality of citizens, and it was in this guise that it took an important place in the electoral programmes of parties such as Nidaa Tounes, AlMassar party and the Popular Front, the Machrouu Tounes (Tunisian Project) movement.

The reaction of civil society organizations was probably predictable: traditional, conservative and proIslamic organizations debated with liberal, human rights, pro-democratic and youth ones. The sheikhs of the Great Mosque of Al-Zaytouna and the Association for the Protection of the Quran, who tried to convict Caid Essebsi of blasphemy and assaulting of the Quran, stood up to defend the Islamic foundations. Moreover, the idea of inheritance equality came into the focus of discussion far beyond the Carthage Palace. For example, Sheikhs and Imams of Al-Azhar in Egypt, fearing a dangerous precedent to take place, immediately noted that the bill contradicts Sharia law and blatantly violates what is written in the Holly Quran.

Surprisingly, the most influential trade union in the country, UGTT, was also critical of the bill which was introduced "prematurely". At the same time, the UGTT did not publish any detailed official position, as there were as many opponents of absolute gender equality in the ranks of the UGTT, including the UGTT general secretary Noureddine Taboubi, as its proponents, including Dr. Sami Tahri, deputy general secretary and a spokesman of the union.

Thus, despite the fact that Tunisia is a party to many international charts and conventions guaranteeing women's rights and prohibiting discrimination, society is still not prepared to accept it in its absolute form, giving priority to discrimination on the basis of religious precepts. Some political parties used rhetoric to improve the social status of women only in electoral campaigns, but in fact did not consider women to be equal political partners, apparently within their own parties as well. The socio-psychological reasons appear to be patriarchal and traditional thinking towards family basics. In other words, contrary to the progressive legislative framework guaranteeing gender equality, there has not been a qualitative cultural transformation in Tunisian society that could effectively eliminate discrimination in all forms against women. 


\section{RESULTS}

Tunisia has come a long way towards gender equality and remains a model for other Arab countries. Since the 2011 uprising, Tunisian women's organizations came out of total control of authorities and gained leeway (a stage of "democratic feminism"), but their ideological disruption, structural fragmentation and lack of a clear agenda remain a significant problem that prevents from talking about a massive and holistic women's movement in Tunisia. Another difficulty is low participation of young members. A rather interesting trend is the spread of "Islamic feminism".

In the quest for gender parity, Tunisia has made the most obvious progress in education, where prejudices in high school nevertheless influence girls' choice of future profession. The problem of equal political participation became particularly acute in the past 10 years, and the quantitative indicators reveal dynamic and positive changes, for example, in the proportion of women's participation in Parliament and Government. The situation in the labour market, in the light of signs of discrimination, is of extreme concern, especially the high female unemployment rate. At the same time, when the current trends are extrapolated to the long term, an equal distribution of labour forces by gender criterion can be expected.

Despite a broad and progressive legislative framework for guaranteeing women's rights, the mass consciousness of Tunisians maintains a set of ideas and norms on gender inequality generated by Islamic tradition. Hence the discrepancy, first in the existing legislation and present-day reality, and secondly, between the rules of family law (fixed in the CPS) containing elements of Sharia, and the provisions of the Constitution, as well as the accepted international obligations (for instance, the Maputo Protocol bans discrimination against women's inheritance rights).

Thus, it should be noted that gender stereotypes in the public consciousness are the main stumbling rock and sticking point cementing discrimination. To improve the situation in Tunisia, which has so far met by only $40 \%$ the 17th goal "Full Gender Equality in All Spheres of Life" under the African Union Agenda for the period up to 2063 (First continental report, 2020: 85), attention should be drawn 1) to the possibility of creating social structures that would help increase the proportion of women in the labour force; 2) to conduct awareness campaigns in the spirit of reformist Islam, as well as, 3) to strengthen monitoring of the implementation of established anti-discrimination legislation; and certainly 4) to bringing local legislation in line with international commitments.

FUNDING: The authors did not receive any external funding.

CONFLICT OF INTEREST: The author declares no conflicts of interest. 


\section{NOTES:}

1. This ministry worked until 1986 and was dissolved up to 1993.

2. The report of Mounya Raqiq (منية الرقيق), Associate Professor of Sociology at the University of Tunisia, at a round table on 10 March 2021 held online by CAREP.

3. It is envisaged that this obligation is subject to a period of four years.

\section{REFERENCES}

- Al-Quran

- Amin Q. 1900. Al-Mara'a al-jadida [The new woman]. Reprint, Cairo: Dar al-Ma'arif, 1972.

- Annuaire Statuesque de la Tunisie 2014-2018. 2019. Tunis : INS. Retrieved from http://www.ins.tn/publication/annuaire-statistique-de-la-tunisie-2014-2018

- Ben Romdhane M. 2011 Tunisie: état, économie et société. Ressources politiques, légitimation et régulations sociales. Tunis: Sud Editions.

- Bessis S. 1999. Le féminisme institutionnel en Tunisie : Ben Ali et la question féminine . Clio. Femmes, Genre, Histoire. no 9 (1999). Retrieved from http://journals.openedition.org/clio/286 DOI : 10.4000/clio.286

- Brand L.A. 1998. Women, the state, and political liberalization: Middle Eastern and North African experience. ISBN: 9780231112673. New York: Columbia University Press. (

- Changing Laws and Breaking Barriers for Women's Economic Empowerment in Egypt, Jordan, Morocco and Tunisia. 2020. OECD/ ILO/ CAWTAR. Retrieved from https://www.ilo.org/africa/information-resources/publications/WCMS 760505/lang-en/index.htm

- Charrad M. M. 2001. State and women's rights: the making of postcolonial Tunisia, Algeria and Morocco. ISBN: 9780520225763. Berkley and Los Angeles: University of California Press.

- Charrad M. M. 1997. Policy shifts: state, Islam, and gender in Tunisia, 1930s-1990s. Social Politics, 4(2): 284-317. DOI https://doi.org/10.1093/sp/4.2.284

- Daniele G. 2014. Tunisian Women's Activism after the January 14 Revolution: Looking within and towards the Other Side of the Mediterranean. Journal of International Women's Studies, 15(2), 1632. Available at: https://vc.bridgew.edu/jiws/vol15/iss2/2

- First continental report on the implementation of Agenda 2063. 2020. AU, NEPAD. ISBN 978-1928527-22-0. Retrieved from https://library.unccd.int/Details/fullCatalogue/1412

- Ganmy M. 2017. Qararat Essebsi li-salih el-mar'a tusiru djadalan fi tunis [the Decisions of Essebsi in favour of women cause debate in Tunisia] Alarabiya, 14.08.2017. Available at: 
- Global Gender Gap Report 2021. 2021. World Economic Forum. ISBN-13: 978-2-940631-07-0.

Retrieved from https://www.weforum.org/reports/global-gender-gap-report-2021

- Gribaa, Boutheina, Depaoli G. 2014. Profil Genre de la Tunisie (en Arabe). Retrieved from https://eeas.europa.eu/archives/delegations/tunisia/documents/page_content/profil_genretunis ie2014_ar_longue_fr.pdf

- Hālid Aḥmad 1985. Aḍ̂ā' min al-bī’ä̈ al-tūnisīyaä 'alá al-țāhir al-ḥaddād wa niḍāl ğîl [View from Tunisia on Tāhir al-Haddād and the fight of generation]. Tūnis: al-Dār al-Tūnisīyaẗ lil-Našr.

- Haddad T. 1930. Imra'atuna fi al-shari'a wa al-mujtama'a [Our Woman in Law and Society]. Tunis: Maison tunisienne de l'édition.

- Klibi, Ch. 2012. Habib Bourguiba, Radioscopie d'un règne. Tunis: Sud Editions.

- Les Femme en Tunisie, 2000. 2002. Tunis: CREDIF.

- Marzouki, I. 1999. Femmes d'ordre ou désordre de femmes? Tunis: Noir sur Blanc.

- Muhibbu-Din M.O. 2019. Feminism and Modern Islamic Politics: The Fact and the Fallacy. International Journal of Islamic Thought, 15 (2019): 44-59. Available at https://doi.org/10.24035/ijit.15.2019.005

- Murphy, E. C. 2003. Women in Tunisia: Between State Feminism and Economic Reform. In Doumato E.A., Posusney M. P. (Eds.) Women and Globalization in the Arab Middle East. Boulder and London: Lynne Rienner Publishers.

- Pitkin H.F. 1967. The concept of representation. Berkley: University of California Press.

- Recensement Général de la Population et de l'Habitat 2014. Vol. 9 : Caracteristiques économiques de la population. 2017. Tunis : INS.

- Sraieb N. 1997. Tunisie: La Politique Sociale et Culturelle de 1987 a 1997 in Annuaire de l'Afrique du Nord, tom xxxvi, 1997, CNRS Editions: $47-78$.

- The World Bank Data, 2021. Available at:

- Trabelsi H. 2019. Al-musawa fi el-irs miqiyas fi ikhtiyyar ra'is tunis al-muqbil [Gender equality in inheritance is a criteria for choosing next president of Tunisia], Independent Arabia, 06.09.2019. Available at: https://www.independentarabia.com/node/53996/\%D8\%A7\%D9\%84\%D8\%A3\%D8\%AE\%D8 \%A8\%D8\%A7\%D8\%B1/\%D8\%A7\%D9\%84\%D8\%B9\%D8\%A7\%D9\%84\%D9\%85\%D8\%A7\%D9\%84\%D8\%B9\%D8\%B1\%D8\%A8\%D9\%8A/\%D8\%A7\%D9\%84\%D9\%85\%D8\% B3\%D8\%A7\%D9\%88\%D8\%A7\%D8\%A9-\%D9\%81\%D9\%8A\%D8\%A7\%D9\%84\%D8\%A5\%D8\%B1\%D8\%AB$\% \mathrm{D} 9 \% 85 \% \mathrm{D} 9 \% 82 \% \mathrm{D} 9 \% 8 \mathrm{~A} \% \mathrm{D} 8 \% \mathrm{~A} 7 \% \mathrm{D} 8 \% \mathrm{~B} 3-$ \%D9\%84\%D8\%A7\%D8\%AE\%D8\%AA\%D9\%8A\%D8\%A7\%D8\%B1\%D8\%B1\%D8\%A6\%D9\%8A\%D8\%B3-\%D8\%AA\%D9\%88\%D9\%86\%D8\%B3\%D8\%A7\%D9\%84\%D9\%85\%D9\%82\%D8\%A8\%D9\%84 
- Voronchanina N.I. 1998. Women's issue in North Africa countries in Arab countries of West Asia and North Africa, no.3. Moscow: RAS, IIMES.

- World Employment and Social Outlook 2021. The role of digital labour platforms in transforming the world of work. 2021. ILO. ISBN 9789220319413Retrieved from https://www.ilo.org/global/research/global-reports/weso/2021/WCMS_771749/lang-en/index.htm 